\title{
SERTIFIKASI HALAL DALAM PERSEPSI KONSUMEN PADA PRODUK PANGAN DI KABUPATEN BANGKALAN
}

\author{
Galuh Widitya Qomaro \\ Universitas Trunojoyo Madura \\ Email: gwiditya@gmail.com
}

\begin{abstract}
Abstrak
Badan Penyelenggara Jaminan Produk halal (BPJPH) Kementrian Agama menargetkan semua produk yang tempat pemasarannya di Indonesia harus memiliki sertifikat halal di tahun 2019. Tujuan penelitian ini adalah (1). Mengetahui tingkat pemahaman konsumen terhadap sertifikasi halal; (2) Mengetahui persepsi konsumen; dan (3) Menganalisa hubungan tingkat pendidikan, pendapatan. Teknik penelitian yang digunakan dalam penelitian ini adalah survey yang mengambil sampel dari suatu populasi dan menggunakan kuisioner sebagai alat pengumpul data yang pokok. Analisis pengukuran terhadap perspektif konsumen terhadap sertifikasi halal dilakukan dengan metode statistic deskriptif. Analisis hubungan tingkat pendidikan dan tempat belanja konsumen dengan pemahaman tentang sertifikasi halal menggunakan analisa Pearson Correlation melalui program SPSS. Hasil pengolahan data menunjukkan bahwa mayoritas responden mengganggap produk pangan bersertifikat halal memiliki added value daripada produk pangan non label halal. Berdasarkan nilai korelasi dengan menggunakan Pearson Correlation, terdapat korelasi antara tingkat pendidikan dan pengetahuan responden terhadap pengetahuan mereka tentang sertifikasi halal.
\end{abstract}

Keyword: Persepsi Konsumen, Sertifikasi Halal, Produk Pangan.

\begin{abstract}
The Ministry of Religion's Halal Product Guarantee Agency (BPJPH) targets all products that have marketing places in Indonesia to have halal certificates in 2019. The objectives of this study are (1). Knowing the level of consumer understanding of halal certification; (2) Knowing consumer perceptions; and (3) Analyzing the relationship between education level, monthly income. The research technique used in this study is a survey that takes samples from a population and uses questionnaires as a basic data collection tool. The measurement analysis of the consumer's perspective on halal certification is done by descriptive statistical methods. Analysis of the relationship between education level and consumer shopping place with an understanding of halal certification using Pearson Correlation analysis through the SPSS program. The results of data processing show that the majority of respondents consider halalcertified food products to have added value rather than non-label halal food products. Based on the correlation value using Pearson Correlation, there is a correlation between the level of education and the knowledge of respondents to their knowledge of halal certification.
\end{abstract}

Keyword: Consumer Perception, Halal Certification, Food Products. 


\section{Pendahuluan}

Kemajuan teknologi dan ilmu pengetahuan membuat produsen makanan masa kini memanfaatkan iptek dan aneka bahan makanan tambahan pangan. Makanan modern dituntut untuk lebih mudah disajikan sekaligus tetap segar dengan warna, aroma, rasa, dan tekstur yang menggugah selera. Kombinasi tersebut menimbulkan titik kritis produk pangan yang harus dicermati dari berbagai segi. Produk pangan asal hewan, misalnya, harus diproses penyembelihan sesuai syariat Islam. Begitu pula bahan tambahan lain yang halal, hingga proses dan fasilitas pembuatan yang halal. Undang-undang No. 33 Tahun 2014 tentang Iaminan Produk Halal berusaha menyelesaikan kehawatiran masyarakat dengan memberikan aturan yang jelas mengenai penerbitan sertifikat halal. Sertifikat Halal adalah pengakuan kehalalan suatu produk yang dikeluarkan oleh BPJPH berdasarkan fatwa halal tertulis yang dikeluarkan oleh MUI sedangkan label halal adalah tanda kehalalan suatu produk. Pelaku Usaha yang telah memperoleh sertifikat halal wajib mencantumkan label halal pada produknya sesuai bentuk label halal yang berlaku nasional.

Permohonan sertifikat halal diajukan oleh pelaku usaha secara tertulis kepada BPJPH. BPJPH menetapkan LPH untuk melakukan pemeriksaan dan/atau pengujian kehalalan produk. Pemeriksaan kehalalan produk dilakukan oleh Auditor Halal yang dilakukan di lokasi usaha pada saat proses produksi sehingga apabila terdapat bahan yang diragukan kehalalannya, dapat dilakukan pengujian di laboratorium. Pelaku Usaha wajib memberikan informasi kepada Auditor Halal. Penetapan kehalalan produk dilakukan oleh MUI. Sertifikat halal diterbitkan oleh BPJPH sejak mendapatkan keputusan kehalalan produk diterima dari MUI. ${ }^{1}$

Manfaat sertifikasi halal bagi konsumen adalah demi memberikan ketenangan konsumsi karena produk yang dikonsumsi terjamin dan aman. Hal ini tentu menjadi tujuan seluruh konsumen. Apalagi konsumen Muslim yang diperintahkan oleh Allah untuk mengkonsumsi produk halalan thoyiban ${ }^{2}$ sebagai bagian dari maqaasid syariah. Bagi produsen, sertifikasi halal berimplikasi pada pemenangan pasar dalam pasar global karena produk tersebut memiliki unique Selling Point sebagai salah satu cara untuk bersang dengan kompetitor. Produk yang memiliki tersertifikasi halal tentulah produk yang aman dan terjamin sehingga mendapatkan kepercayaan konsumen, apalagi Indonesia merupakan salah satu Negara dengan konsumen Muslim terbesar didunia.

Konsumen, yang didefinisikan sebagai setiap orang pemakai barang dan/atau jasa yang tersedia dalam masyarakat, baik bagi kepentingan diri sendiri, keluarga, orang lain, maupun makhluk hidup lain dan tidak untuk diperdagangkan adalah bagian tak terpisahkan dari rantai konsumsi. ${ }^{3}$ Mendapat informasi yang jujur, benar, dan jelas adalah salah satu hak konsumen yang harus dipenuhi oleh pelaku usaha. Sertifikasi halal adalah bagian dari pemenuhan konsumen atas hak kenyamanan, keamanan, dan keselamatan dalam mengkonsumsi barang dan/atau jasa. Disatu pihak, konsumen menuntut pemenuhan hak namun disisi lain banyak konsumen yang acuh tak acuh atas perkembangan informasi sehingga mengabaikan kewajibannya untuk membaca

\footnotetext{
1 Undang-Undang No. 33 Tahun 2014 Tentang Iaminan Produk Halal

2 Q.S. Al-Baqarah [2]: 168 Dan Q.S. Al-Mâidah [3]: 88

3 Undang-Undang No. 08 Tahun 1999 Tentang Perlindungan Konsumen
} 
atau mengikuti petunjuk informasi dan prosedur pemakaian atau pemanfaatan barang dan/atau jasa, demi keamanan dan keselamatan.

Peraturan Presiden No. 131/2015 tentang Penetapan Daerah Tertinggal Tahun 2015-2019 menyebutkan bahwa Bangkalan merupakan salah satu kabupaten di Jawa Timur yang ditetapkan sebagai daerah tertinggal. Kenyataan bahwa Kabupaten Bangkalan memliliki akses yang strategis dengan Surabaya sebagai ibukota Jawa Timur ternyata kurang dapat berkontribusi positif terhadap perekonomian, sumberdaya manusia, sarana dan prasarana, kemampuan keuangan daerah, aksesbilitas, dan karakteristik daerah.

\section{Metode Penelitian}

Penelitian ini bersifat deskriptif dengan menggunakan pendekatan kuantitatif. Teknik penelitian yang digunakan dalam penelitian ini adalah survey yang mengambil sampel dari suatu populasi dan menggunakan kuisioner sebagai alat pengumpul data yang pokok. Analisis pengukuran terhadap perspektif konsumen terhadap sertifikasi halal dilakukan dengan metode statistic deskriptif. Analisis hubungan profil demografis yang meliputi jenis kelamin, usia, dan profesi konsumen dengan sertifikasi halal menggunakan analisa tabulasi silang menggunakan program SPSS.

Pada penelitian ini, pengambilan sampel dilakukan secara bertahap menggunakan area (cluster) sampling dan dilanjutkan dengan purposive sampling. Area (cluster) sampling adalah teknik sampling daerah yang digunakan untuk menentukan sampel yang diteliti atau sumber data yang sangat luas, misalnya penduduk kabupaten. ${ }^{4}$ Sedangkan purposive sampling yaitu teknik sampling yang digunakan peneliti jika peneliti mempunyai pertimbangan tertentu dalam pengambilan sampel. ${ }^{5}$

Berdasarkan data Badan Pusat Statistik Kabupaten Bangkalan, jumlah penduduk Kabupaten Bangkalan yang tersebar pada delapan belas (18) kecamatan sebanyak 900.556 jiwa dan diambil sampel yang memenuhi criteria yang telah ditetapkan sehingga sampel yang terpilih sesuai dengan kebutuhan penelitian hingga mendapatkan 72 orang sampel. Dalam penelitian ini, pengambilan sampel dilakukan secara terarah berdasarkan beberapa kriteria yang dianggap mewakili populasi, diantaranya menurut usia, pekerjaan, tingkat pendidikan, jumlah pendapatan, dan tempat belanja dengan harapan dapat diketahui hasilnya pada persepsi konsumen terhadap sertifikasi halal pada produk pangan.

\section{Metode Pengumpulan Data}

Data primer adalah data yang belum tersedia dan harus diperoleh dari sumber aslinya. ${ }^{6}$ Pada penelitian ini, data primer diperoleh melalui pengisian kuisioner oleh responden secara langsung serta melalui hasil wawancara dengan responden untuk menunjang keakuratan data kuisioner. Data sekunder adalah data yang telah tersedia dimana peneliti hanya perlu mencari tempat untuk mendapatkannya. ${ }^{7}$ Pada penelitian ini, data sekunder yang digunakan adalah

\footnotetext{
${ }^{4}$ Ibid, 83.

${ }^{5}$ Riduwan, Dasar-Dasar Statistika, (Bandung: Alfabeta, 2013), 20.

${ }^{6}$ Sinamora, B. Panduan Riset Perilaku Konsumen. (Jakarta: PT Gramedia Pustaka Utama, 2002).

${ }^{7}$ Ibid.
} 
data yang diperoleh peneliti dari buku/literatur, situs internet serta laporan beberapa instansi seperti data kependudukan dan keadaan lokasi.

\section{Analisis Data}

Pengujian validitas kuisioner dilakukan dengan menggunakan rumus teknik korelasi product moment, dimana masing-masing pertanyaan akan dikorelasikan dengan nilai total. Indeks korelasi yang dipeoleh (r) dibandingkan dengan angka kritis pada tabel korelasi nilai "r". Jika nilai korelasi yang diperoleh di atas angka kritisnya, maka pertanyaan tersebut signifikan atau valid. Pengujian validitas dan reliabilitas kuisioner dilakukan terhadap 72 orang responden dengan bantuan SPSS versi 22.

Suatu instrumen penelitian dikatakan mempunyai nilai yang reliabilitas tinggi, apabila tes (alat pengumpul data) yang dibuat mempunyai hasil yang konsisten dalam mengukur yang hendak diukur. Reliabilitas menujukkan pada satu pengertian bahwa satu instrumen cukup dapat dipercaya untuk digunakan sebagai alat pengumpul data. Instrumen yang reliabel akan menghasilkan data yang dapat dipercaya.

Sebuah instrumen jika sudah dinyatakan "valid" biasanya "reliabel", sehingga uji validitas sangat penting untuk dilakukan, sedangkan uji reliabilitas dilakukan sekedar untuk memastikan dan mengetahui seberapa besar reliabel sebuah instrumen tersebut.

Indikator Pengukuran Variabel

Variabel Persepsi Konsumen ${ }^{8}$

\begin{tabular}{|c|c|c|}
\hline No & Variabel & $\begin{array}{c}\text { Indikator } \\
\text { (Pengukuran menggunakan skala Likert) }\end{array}$ \\
\hline \multirow[t]{3}{*}{1} & \multirow{3}{*}{$\begin{array}{l}\text { Persepsi } \\
\text { Kualitas }\end{array}$} & Semua produk pada dasarnya memiliki kualitas yang sama. \\
\hline & & $\begin{array}{l}\text { Adanya perbedaan yang mencolok pada kemasan produk } \\
\text { berlabel halal dengan produk tanpa label halal lainnya. }\end{array}$ \\
\hline & & $\begin{array}{l}\text { Kualitas produk berlabel halal tidak jauh berbeda dengan } \\
\text { produk tanpa label halal lainnya. }\end{array}$ \\
\hline \multirow[t]{3}{*}{2} & \multirow[t]{3}{*}{$\begin{array}{l}\text { Persepsi } \\
\text { Nilai }\end{array}$} & $\begin{array}{l}\text { Produk berlabel halal memiliki nilai tersendiri bagi saya } \\
\text { dibandingkanproduk tanpa label halal lainnya }\end{array}$ \\
\hline & & $\begin{array}{l}\text { Produk berlabel halal memilikimanfaat dalam memenuhi } \\
\text { kebutuhan saya. }\end{array}$ \\
\hline & & $\begin{array}{l}\text { Manfaat yang diberikan pada produk berlabel halal sesuai } \\
\text { dengan harga yang dibayarkan }\end{array}$ \\
\hline
\end{tabular}

Variabel Sertifikasi Halal ${ }^{9}$

\begin{tabular}{|c|l|}
\hline No & \multicolumn{1}{|c|}{\begin{tabular}{c}
\multicolumn{1}{|c|}{ Indikator } \\
(Pengukuran menggunakan skala Likert)
\end{tabular}} \\
\hline 1 & $\begin{array}{l}\text { Terdapat logo halal dalam kemasan produk makanan adalah hal yang } \\
\text { penting }\end{array}$ \\
\hline
\end{tabular}

8 Johanes. Analisis Pengaruh Persepsi Konsumen. 2012.

${ }_{9}$ Shaari dan Arifin, Pengaruh Sertifikasi Halal. 2010. 


\begin{tabular}{|l|l|}
\hline 2 & $\begin{array}{l}\text { Logo halal menjadi pertimbangan saya dalam membeli produk } \\
\text { makanan }\end{array}$ \\
\hline 3 & $\begin{array}{l}\text { Saya akan memilih produk berdasarkan ada } \\
\text { tidaknya logo halal }\end{array}$ \\
\hline 4 & Saya akan berhati-hati ketika memilih produk dengan logo halal \\
\hline 5 & Saya akan tetap membeli produk dari negara lain yang berlogo halal \\
\hline 6 & Saya mengetahui logo halal otentik dari MUI \\
\hline 7 & $\begin{array}{l}\text { Saya dapat membedakan mana logo halal otentik dari MUI dan logo } \\
\text { halal yang tidak otentik }\end{array}$ \\
\hline 8 & $\begin{array}{l}\text { Saya mengetahui bahwa beberapa produk mendapat sertifikasi halal } \\
\text { dari negara lain }\end{array}$ \\
\hline 9 & Saya merasa aman mengkonsumsi produk berlogo halal \\
\hline 10 & $\begin{array}{l}\text { Saya tetap akan membeli produk halal tanpa mempertimbangkan } \\
\text { perusahaan apa yang memproduksi }\end{array}$ \\
\hline 11 & Saya tidak mempermasalahkan lembaga yang membuat logo halal \\
\hline 12 & $\begin{array}{l}\text { Saya lebih memilih produk makanan berlogo halal dari pada produk } \\
\text { yang tidak memiliki logo halal }\end{array}$ \\
\hline 13 & Produk berlogo halal tidak mengandung najis \\
\hline 14 & Produk bersertifikat halal berkualitas \\
\hline 15 & Saya tidak ragu untuk mengkonsumsi makanan berlogo halal \\
\hline 16 & $\begin{array}{l}\text { Produk berlogo halal telah melalui serangkaian proses uji halal yang } \\
\text { ketat }\end{array}$ \\
\hline 17 & Produk berlogo halal telah lolos tes uji halal oleh MUI \\
\hline
\end{tabular}

\section{Gambaran Umum Objek Penelitian Kabupaten Bangkalan}

Pemerintah Kabupaten Bangkalan berkedudukan di Jalan Soekarno Hatta No. 35 Kelurahan Mlajah Kecamatan Bangkalan Kabupaten Bangkalan. Luas Wilayah Kabupaten Bangkalan 1.260,14 km2 terbagi dalam 18 Kecamatan 8 Kelurahan dan 273 Desa. Kabupaten Bangkalan terletak di antara koordinat 1120 40'06" - 1130 08'04" Bujur Timur serta 60 51'39" - 70 11'39" Lintang Selatan. Wilayah Kabupaten Bangkalan yang terletak di pesisir pantai di antaranya kecamatan Sepulu, Bangkalan, Socah, Kamal, Modung, Kwanyar, Arosbaya, Klampis, Tanjung Bumi dan Labang. Sedangkan wilayah Bangkalan yang berbukit-bukit mulai dari Burneh, Geger, Kokop, Tragah, Tanah Merah, Labang, Konang dan Galis. Bangkalan merupakan salah satu kabupaten yang terletak paling barat di kepulauan Madura. ${ }^{10}$

Pulau Madura merupakan bagian dari Propinsi Jawa Timur yang terpisah dari kabupaten-kabupaten lain yang masuk dalam Propinsi Jawa Timur. Salah satu pusat kegiatan untuk mendukung proses pembangunan dan pengembangan wilayah kota Bangkalan adalah dengan adanya Jembatan Suramadu, juga pengembangan pembangunan pascajembatan Suramadu bagian barat. Pengembangan tersebut meliputi pusat kegiatan pemerintahan, perdagangan dan jasa, pelayanan umum (transportasi, kesehatan, peribadatan, pendidikan, dan lainnya) dengan skala regional Kabupaten Bangkalan

${ }^{10}$ Bapedda.jatimprov.go.id diakses pada 15 Juli 2018 


\section{Profil Responden}

Profil responden dari penelitian ini dilihat dari usia, pendidikan, pekerjaan, besaran pendapatan bulanan, akses penerimaan informasi, dan tempat belanja kebutuhan harian. Dari hasil survei yang telah dilakukan dengan responden sebanyak 72 orang responden pada Tabel 2, rentang usia terbanyak adalah 2530 tahun sebesar $25 \%$ disusul rentang usia 40-60 tahun sebesar $22.3 \%$.

Berdasarkan tingkat pendidikan, responden terbagi atas enam kelompok. Responden paling banyak adalah responden yang rata-rata berpendidikan SMA $45.8 \%$ kemudian sebanyak $26.4 \%$ berpendidikan Sarjana serta berpendidikan sekolah dasar $19.4 \%$ serta sekolah lanjut tingkat pertama $6 \%$. Sebaran tingkat pendidikan responden dalam penelitian ini menunjukkan bahwa responden dinilai cukup mampu mengakses informasi yang diperlukan untuk kelangsungan dan kesejahteraan keluarganya. Selain itu, responden juga dinilai cukup mampu memahami instruksi yang diberikan peneliti lewat kuisioner selama pengambilan data, sehingga menunjang tercapainya tujuan penelitian.

Berdasarkan pekerjaan yang digeluti, profesi Mahasiswa, Pedagang dan lainnya memiliki porsi yang sama yaitu 25\%. Profesi lain yang diisikan oleh responden meliputi: Pemuka Agama, Perangkat Desa, TNI/Polisi, dan Ibu Rumah Tangga. Karyawan Swasta dan Pegawai negeri Sipil juga mendapatkan jumlah yang sama yaitu $12.5 \%$.

Berdasarkan tingkat pendapatan, sebagai perbandingan dengan sebaran responden berdasarkan pekerjaan, responden terbanyak memiliki pendapatan bulanan sebesar Rp. 500.000 - Rp. 1.000 .000 sebanyak 30.2\% disusul dengan responden dengan pendapatan bulanan sebanyak kurang dari Rp. 500.000 perbulan lalu disusul dengan pendapatan bulanan sebanyak Rp. 1.000 .000 - Rp. 2.000.000 perbulan. $9.8 \%$ responden menjawab lainnya karena merasa pendapatan perbulannya tidak dapat ditentukan (tidak pasti).

Berdasarkan akses terhadap informasi dimana responden mendapatkan pengetahuan tentang sertifikasi halal, pertemuan agama/ ceramah agama menempati posisi tertinggi dengan $38.9 \%$ sebagai tempat terbanyak memdapatkan informasi. Disusul dengan internet sebanyak 26.5\% responden dan mendapatkan informasi dari media televise sebanyak 20.8\%. 6.9\% responden menjawab lainnya karena mereka mendapatkan informasi dari teman maupun penjual produk saat responden berbelanja.

Berdasarkan tempat belanja untuk memenuhi kebutuhan harian, dapat diklasifikasikan bahwa pasar tradisional masih menjadi tempat favorit untuk berbelanja kebutuhan harian dengan perolehan $66.7 \%$ lalu disusul oleh swalayan. Supermarket sebagai tempat berbelanja 18\% responden dan toko kelontong terdekat dengan rumah responden sebanyak $12.5 \%$. Pedagang keliling dan online shop ternyata masih kurang diminati terbukti dari hasil jawaban kuisioner sebanyak $1.4 \%$.

\section{Hasil Uji Validitas dan Reliabilitas}

Teknik yang digunakan untuk mengetahui tingkat validitas instrument adalah product moment yang dikemukakan oleh Pearson. Adapun pengujian dilakukan pada item-item instrumen. Apabila terdapat 10 item intrumen dan dinyatakan "valid" sebanyak 7 item, sisanya dinyatakan "tidak valid", maka perlu dilakukan uji validitas lagi dengan instrument yang berbeda. Adapun kriteria 
pengambilan keputusan yang digunakan pada Uji validitas dengan bantuan SPSS for windows adalah sebagai berikut:

a) Jika sig. $<0.05$, maka dinyatakan valid.

b) Jika sig. $>0.05$, maka dinyatakan tidak valid

Untuk mengetahui persepsi responden terhadap sertifikasi halal, disajikan 6 butir pernyataan terkait persepsi nilai dan kualitas, serta 17 butir pernyataan tentang sertifikasi halal. Seluruh instrument menggunakan skala likert dengan jumlah responden sebanyak 72 orang. Table hasil uji coba instrumen dapat dilihat pada lampiran.

Berdasarkan tabel uji coba instrument untuk pengukuran validitas dapat disimpulkan bahwa dari 6 item instrument pada persepsi nilai dan kualitas dinyatakan valid. Pada item nomor 11 (dari keseluruhan 17 item untuk instrument sertifikasi halal) dalam instrumen mengenai sertifikasi halal tidak valid karena memiliki sig $>0.05(0.179)$ sehingga item tersebut dihapuskan. Setelah menghapus satu item yang tidak valid, maka seluruh instrumen penelitian dinyatakan memenuhi syarat validitas dan siap dianalisa. Kriteria pengambilan keputusan yang digunakan pada Uji Reliabilitas dengan bantuan SPSS for windows adalah sebagai berikut:

a) Jika nilai Cronbach's Alpha $>0.6$, maka dinyatakan reliabel.

b) Jika nilai Cronbach's Alpha $<0.6$, maka dinyatakan tidak reliabel. berikut.

Hasil Output dari uji reliabilitas memiliki nilai Cronbach's Alpha sebagai

Reliability Statistics

\begin{tabular}{|r|r|}
\hline $\begin{array}{c}\text { Cronbach's } \\
\text { Alpha }\end{array}$ & N of Items \\
\hline .608 & 6 \\
\hline
\end{tabular}

Nilai Cronbach's Alpha pada variable persepsi sebesar 0,608 0,6 dan nilai Cronbach's Alpha pada variable sertifikasi halal sebesar 0,788 $>0,6$ artinya seluruh instrument angket tersebut reliabel (dapat dipercaya).

\section{Pembahasan}

\section{Karakteristik Persepsi Kualitas Responden}

Persepsi responden terhadap kualitas tercermin dari pertanyaan nomor 1 hingga 3. Pernyataan pertama bahwa semua produk pada dasarnya memiliki kualitas yang sama, ditanggapi beragam oleh responden. 45\% responden menjawab tidak setuju atas pernyataan tersebut dan $23.7 \%$ menjawab kurang setuju bila disebut seluruh produk dianggap memiliki kualitas yang sama. Hanya $2.8 \%$ responden menyetujui pernyataan bahwa seluruh produk pada dasarnya berkualitas setara.

Pernyataan kedua menyebutkan tentang adanya perbedaan yang mencolok pada kemasan produk berlabel halal dengan produk tanpa label halal lainnya. Anggapan yang dibangun karena produk dengan label halal tentunya harus memenuhi unsur kualitas kemasan yang sudah ditentukan oleh BPOM ataupun MUI. 37.2\% responden setuju tentang adanya perbedaan yang mencolok dari kemasan produk dengan label halal dan $26 \%$ responden menjawab kurang setuju atas pernyataan tersebut. $5.5 \%$ responden menganggap tidak ada perbedaan kemasan antara produk berlabel halal maupun produk tanpa label halal. 
Responden menilai kualitas produk berlabel halal merespon pernyataan ketiga dengan beragam. 35\% responden tidak setuju dengan pernyataan bahwa kualitas produk berlabel halal tidak jauh beda dengan produk tanpa label halal. 28.8\% responden kurang setuju dengan pernyataan tersebut. namun $21.3 \%$ responden menyetujui pernyataan bahwa produk dengan label halal maupun tanpa label halal sebenarnya memiliki kualitak yang tidak jaug berbeda.

\section{Persepsi Nilai Responden}

Persepsi responden terhadap nilai produk ditampilkan pada tiga pernyataan nomor 4, 5, dan 6. Pernyataan bahwa produk berlabel halal memiliki nilai tersendiri bagi responden dibandingkan produk tanpa label halal lainnya disetujui oleh $57.1 \%$ responden dan $30.4 \%$ responden sangat setuju dengan pernyataan tersebut. $1.1 \%$ responden menganggap bahwa produk dengan label halal memiliki nilai yang sama dengan produk tanpa label halal.

Sebanya $54.1 \%$ responden menyatakan setuju bila produk berlabel halal bermanfaat dalam memenuhi kebutuhan responden disusul dengan 30.5\% responden yang sangat setuju dengan pernyataan tersebut. Hanya 2.4\% responden yang menyatakan tidak setuju bila disebut bahwa produk berlabel halal dapat memenuhi kebutuhannya.

Mengenai persepsi nilai terkait kesesuaian harga ditunjukkan dengan pernyataan bahwa manfaat yang diberikan oleh produk berlabel halal sesuai dengan harga yang dibayarkan disetujui oleh 57\% responden. Sebanyak 25.2\% responden menyatakan kurang setuju karena menganggap produk berlabel halal memiliki harga yang lebih tinggi daripada produk lain sejenis.

\section{Pengetahuan Halal Responden}

Tingkat pengetahuan responden tentang halal dapat diketahui dari jawaban-jawaban yang diberikan responden atas beberapa pertanyaan yang diajukan pada kuisioner tertutup pada nomor 6, 7, 8, 13, 16, dan 17. Pertanyaan tersebut meliputi apakah responden mengetahui tentang logo halal yang asli, proses mendapatkan sertifikat halal, dan bahan makanan pada produk berlabel halal dan prosedur pendaftaran sertifikasi halal.

Pernyataan bahwa responden mengetahui tentang logo halal otentik dari MUI/BPJPH dijawab setuju oleh 38.8\% responden. Sebanyak 23.5\% responden kurang tahu akan logo halal yang otentik yang dikeluarkan oleh MUI/BPJPH. Responden yang tidak tahu dan responden yang sangat mengetahui mengenai keontentikan logo ini memiliki prosentase yang sama yaitu $9 \%$ responden.

Kemampuan responden untuk membedakan antara logo halal yang asli dari MUI/BPJPH dengan logo halal yang palsu disebutkan dalam pernyataan ke tujuh. Sebanyak 36.4\% responden mampu membedakan antara logo halal yang asli dengan yang palsu, sedangkan $35.7 \%$ responden kurang mampu membedakan diantara keduanya. Hanya $1.7 \%$ responden yang benar-benar tidak mampu membedakan antara logo halal yang asli maupun palsu.

Pengetahuan responden mengenai penerbitan label halal dari Negara lain dimunculkan pada pernyataan butir ke delapan. Pernyataan ini menghasilkan jawaban yang tidak jauh beda tingkat prosentasenya antara $23 \%$ responden yang tidak mengetahui bahwa Negara lain dapat menerbitkan sertifikat halal untuk produk yang dijual di Indonesia. Sebanyak 35\% persen responden mengetahui 
hal tersebut dan 35.5\% lainnya kurang mengetahui bahwa Negara lain dapat menerbitkan sertifikat halal untuk sebuah produk yang dijual di Indonesia.

Mengenai bahan pangan yang tidak mengandung najis pada produk berlabel halal sudah diketahui oleh $56.6 \%$ responden. Sebanyak $26.4 \%$ bahkan sangat mengetahui bahwa bahan najis tidak mungkin ada pada produk pangan berlabel halal. Tidak ada responden yang tidak tahu atau bahkan sangat tidak tahu tentang hal ini. Hanya saja sebanyak 17\% responden masih kurang mengetahui bahwa produk pangan berlogo halal tidak mengandung najis.

Proses pengujian halal yang ketat terhadap produk pangan berlabel halal diketahui oleh $63.9 \%$ responden dan $29.1 \%$ responden bahkan sangat setuju akan pernyataan tersebut. Hanya $2.5 \%$ responden yang kurang setuju akan pernyataan bahwa produk berlogo halal telah melalui proses uji halal yang ketat.

Senada dengan pernyataan sebelumnya, item nomer tujuh belas menyebutkan bahwa produk berlogo halal telah lolos tes uji halal oleh MUI. Sebanyak 58.6\% responden menyetujui pernyataan tersebut. Sebanyak 34.5\% sangat setuju dan $1.4 \%$ responden kuran setuju bahwa produk berlogo halal telah lolos uji halal oleh MUI.

\section{Sebaran Demografis Persepsi Responden tentang Sertifikasi Halal}

Dasar pengambilan keputusan dalam analisis korelasi yakni dengan melihat nilai signifikansi ${ }^{11}$ dan tanda bintang ${ }^{12}$ yang diberikan pada output program SPSS. Berdasarkan korelasi Pearson dapat diketahui bahwa nilai signifikansi antara tingkat pendidikan dengan pengetahuan responden tentang sertifikasi halal adalah $.035<.05$ maka disimpulkan bahwa terdapat korelasi antara tingkat pendidikan dan pengetahuan responden terhadap pengetahuan mereka tentang sertifikasi halal. Berikut ini adalah tabulasi hubungan antara tingkat pendidikan dengan tingkat pengetahuan responden tentang sertifikasi halal

\begin{tabular}{|c|c|c|c|}
\hline \multicolumn{4}{|c|}{ Correlations } \\
\hline & & $\begin{array}{c}\text { Sertifikasi } \\
\text { Point } \\
6,7,12,16\end{array}$ & Pendidikan \\
\hline \multirow[t]{3}{*}{ Sertifikasi Point $6,7,12,16$} & Pearson Correlation & 1 & .077 \\
\hline & Sig. (2-tailed) & & .035 \\
\hline & $\mathrm{N}$ & 4 & 3 \\
\hline \multirow[t]{3}{*}{ Pendidikan } & Pearson Correlation & .077 & 1 \\
\hline & Sig. (2-tailed) & .035 & \\
\hline & $\mathrm{N}$ & 3 & 3 \\
\hline
\end{tabular}

Responden dikelompokkan juga berdasarkan pendapatan bulanan yang dihasilkan. Berdasarkan korelasi dengan menggunakan Pearson, didapat bahwa besarnya pendapatan tidak hubungan dengan tingkat pengetahuan mengenai sertifikasi halal. Berikut adalah table hubungan antara tingkat pendapatan dengan tingkat pengetahuan mengenai sertifikasi halal

\footnotetext{
11 Jika nilai signifikansi $<0.05$ maka terdapat korelasi, sebaliknya jika nilai signifikansi $>0.05$ maka tidak terdapat korelasi

12 Jika terdapat tanda bintang pada person correlation maka antara variable yang dianalisa terjadi korelasi, sebaliknya jika tidak terdapat tanda bintang maka tidak terjadi korelasi antara variable.
} 


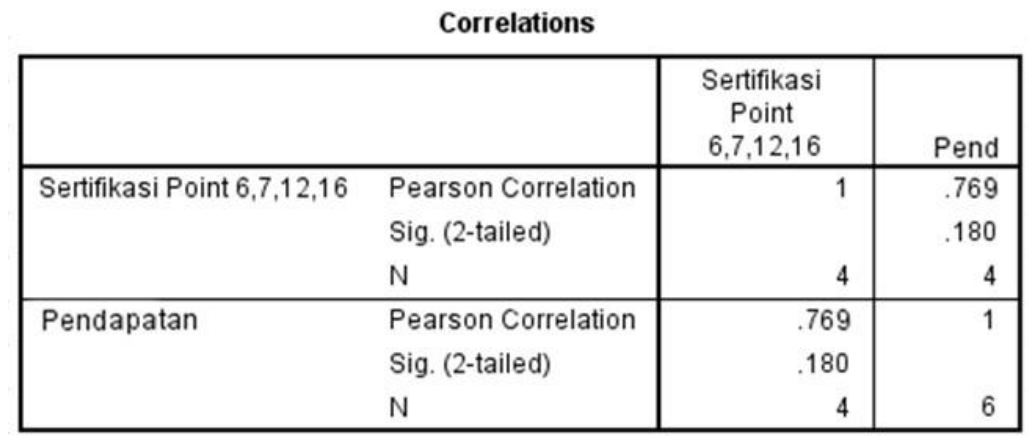

Berdasarkan tabel berikut, dapat diketahui bahwa tidak terdapat hubungan antara pengetahuan responden tentang halal dengan tempat responden memenuhi kebutuhan sehari-hari.

Correlations

\begin{tabular}{|ll|r|r|}
\hline & \multicolumn{1}{|c|}{$\begin{array}{c}\text { Sertifikasi } \\
\text { Point } \\
6,7,12,16\end{array}$} & Belanja \\
\hline Sertifikasi Point $6,7,12,16$ & Pearson Correlation & 1 & -.547 \\
& Sig. (2-tailed) & .453 \\
& $\mathrm{~N}$ & 4 & 4 \\
\hline Belanja & Pearson Correlation & -.547 & 1 \\
& Sig. (2-tailed) & .453 & \\
& $\mathrm{~N}$ & 4 & 5 \\
\hline
\end{tabular}

\section{Kesimpulan}

Seluruh instrumen penelitian dinyatakan memenuhi syarat validitas dan siap dianalisa karena sig. $<0.05$. Nilai Cronbach's Alpha pada variable persepsi sebesar 0,608 > 0,6 dan nilai Cronbach's Alpha pada variable sertifikasi halal sebesar 0,788 $>0,6$ artinya seluruh instrument angket tersebut reliabel (dapat dipercaya).

Berdasarkan nilai terbanyak, sebanyak 45\% responden mengganggap bahwa produk pangan dengan label halal memiliki kualitas yang berbeda dengan produk pangan tanpa label halal. Sebanya 37.2\% dapat mengetahui perbedaan produk pangan berlabel halal karena kemasannya yang mencolok (memiliki label halal). Sebanyak 57.1\% responden menyebutkan bahwa produk pangan berlabel halal memiliki nilai tersendiri bagi responden dibandingkan produk tanpa label halal. Sebanyak 54.1\% responden menyatakan setuju bila produk berlabel halal bermanfaat dalam memenuhi kebutuhan responden. Mengenai persepsi nilai terkait kesesuaian harga ditunjukkan dengan pernyataan bahwa manfaat yang diberikan oleh produk berlabel halal sesuai dengan harga yang dibayarkan disetujui oleh $57 \%$ responden.

Mengenai tingkat pengetahuan halal, 38.8\% responden mengetahui tentang logo halal otentik dari MUI/BPJPH. Sebanyak 36.4\% responden mampu membedakan antara logo halal yang asli dengan yang palsu. 35.5\% responden kurang mengetahui bahwa Negara lain dapat menerbitkan sertifikat halal untuk sebuah produk yang dijual di Indonesia. 56.6\% responden mengetahui bahwa bahan makanan dalam produk pangan berlabel halal tidak mengandung najis. 
Proses pengujian halal yang ketat terhadap produk pangan berlabel halal diketahui oleh $63.9 \%$ responden.

Berdasarkan nilai korelasi dengan menggunakan Pearson Correlation, terdapat korelasi antara tingkat pendidikan dan pengetahuan responden terhadap pengetahuan mereka tentang sertifikasi halal namun tidak terdapat hubungan antara tingkat pendapatan bulanan dan tempat responden berbelanja bulanan dengan kepemilikan pengetahuan responden tersebut tentang sertifikasi halal.

\section{Daftar Pustaka}

Johanes, Purba Setiawan. Analisis Pengaruh Persepsi Konsumen Terhadap Keputusan Pembelian Produk Private Label Hypermarket Carrefour (Semarang. Tesis, 2012).

Mahmudah, Risma Nurul, Persepsi Konsumen terhadap Keputusan Pembelian Pakaian Wanita di media Sosial pada Toko Vieney Online Shop (Studi Kasus di Akbid Al-Suaibah (Palembang, Skripsi, 2015).

Pebriani, Yuditia Dwi. Pengaruh Persepsi Konsumen Terhadap Keputusan Pembelian Produk Merek Pribadi (Studi Pada Indomaret Di Ratu Dibalau), (Skripsi, 2016)

Philip Kotler, Kevin Lane Keller, Manajemen Pemasaran, (Indonesia: Macanan Jaya Cemerlang, 2008)

Ramlan, Sertifikasi Halal Sebagai Penerapan Etika Bisnis Islami Dalam Upaya Perlindungan Bagi Konsumen Muslim, Jurnal Ahkam: Vol. XIV, No. 1, Januari, 2014,145

Sinamora, B. Panduan Riset Perilaku Konsumen (Jakarta: PT Gramedia Pustaka Utama, 2002)

Singarimbun, M dan S. Efendi. Metode Penelitian Survei. (Jakarta: LP3ES, 1995).

Sugiarto, Siagian D, Sunaryanto, L S dan Oetomo, D S. Teknik Sampling. Jakarta: PT Gramedia Pustaka Utama, 2003)

Suryani, Tatik. Perilaku Konsumen: Implikasi Pada Strategi Pemasaran. Edisi Pertama. (Graha Ilmu, 2012)

Syahputra, Adi. Pengaruh Labelisasi Halal Terhadap Keputusan Masyarakat Kecamatan Perbaungan Dalam Pembelian Produk Makanan Dalam Kemasan, Jurnal Ekonomi dan Keuangan, 2013, Vol.2 No.8, 475

Undang-Undang No. 08 Tahun 1999 Tentang Perlindungan Konsumen

Undang-Undang No. 33 Tahun 2014 Tentang Iaminan Produk Halal

Waskito, Danang. Pengaruh Sertifikasi Halal, Kesadaran Halal, Dan Bahan Makanan Terhadap Minat Beli Produk Makanan Halal (Studi Pada Mahasiswa Muslim Di Yogyakarta), (Skripsi, 2015)

Yuli Mutiah Rambe, Pengaruh Pencantuman Label Halal Pada Kemasan Mie Instan Terhadap Minat Pembelian Masyarakat Muslim (Studi Kasus Pada Mahasiswa Universitas Al-Washliyah, Medan), Jurnal Ekonomi dan Keuangan, Vol. 1, No. 1, Desember 2012. 